\title{
RETRACTED: A low-cost in-house HIV integrase strand transfer inhibitor drug resistance test for resource-limited settings [version 1; peer review: not peer reviewed]
}

\author{
Vera M. Onwong'a(i)1,2, Rachael W. Gachogo (D1,3, Moses M. Masika(iD2, \\ Graeme B. Jacobs (D) 4, Frank G. Onyambu(D1,5 \\ ${ }^{1}$ Molecular \& Infectious Diseases Research Laboratory, University of Nairobi, Nairobi, Kenya \\ ${ }^{2}$ Department of Medical Microbiology, University of Nairobi, Nairobi, Kenya \\ 3International Livestock Research Institute, Nairobi, Kenya \\ ${ }^{4}$ Division of Medical Virology, Department of Pathology, Stellenbosch University, Stellenbosch, South Africa \\ ${ }^{5}$ School of Health Sciences, Meru University of Science and Technology, Meru, Kenya
}

V1 First published: 20 Apr 2021, 10:306

https://doi.org/10.12688/f1000research.52954.1

Latest published: 20 Apr 2021, 10:306

https://doi.org/10.12688/f1000research.52954.1

At the request of the authors, the article titled 'A low-cost in-house HIV integrase strand transfer inhibitor drug resistance test for resource-limited settings' ([version 1; peer review: awaiting peer

review]. F1000Research 2021, 10:260,

https://doi.org/10.12688/f1000research.28404.1) has been retracted

from F1000Research.

Since publication, it has come to the attention of the authors that the primers described in Table 1 were incorrect. As this article contains information which should not be publicly available the content of the article has been removed. The authors apologise for this honest error, and intend to republish the article with the correct primer information. Unfortunately, Dr Graeme B. Jacobs has passed away since publication of version 1 of this article.

\section{Keywords}

HIV, HIV Drug Resistance, Drug Resistance Testing (DRT), Integrase Strand Transfer Inhibitors (INSTIs), Assay Validation, Accuracy,

Precision, Reproducibility, Amplification

\section{Not Peer Reviewed}

This article is an Retraction and has not been subject to external peer review.

Any comments on the article can be found at the end of the article. 


\section{Associated Research Article}

Onwong'a VM, Gachogo RW, Masika MM et al. » A low-cost in-house HIV integrase strand transfer inhibitor drug resistance test for resource-limited settings, F1000Research 2021, 10:260 (https://doi.org/10.12688/f1000research.28404.1)

Corresponding author: Frank G. Onyambu (frank.onyambu@iscb.org)

Author roles: Onwong'a VM: Conceptualization, Data Curation, Formal Analysis, Investigation, Methodology, Writing - Original Draft Preparation, Writing - Review \& Editing; Gachogo RW: Investigation, Methodology, Writing - Review \& Editing; Masika MM: Supervision, Writing - Review \& Editing; Jacobs GB: Supervision, Writing - Review \& Editing; Onyambu FG: Conceptualization, Formal Analysis, Funding Acquisition, Methodology, Project Administration, Supervision

Competing interests: No competing interests were disclosed.

Grant information: This work was supported by Interhealth Networks Africa scholarship INA-001 awarded to VMO. The content is solely the responsibility of the authors and does not represent views of the funders.

The funders had no role in study design, data collection and analysis, decision to publish, or preparation of the manuscript.

Copyright: @ 2021 Onwong'a VM et al. This is an open access article distributed under the terms of the Creative Commons Attribution License, which permits unrestricted use, distribution, and reproduction in any medium, provided the original work is properly cited.

How to cite this article: Onwong'a VM, Gachogo RW, Masika MM et al. RETRACTED: A low-cost in-house HIV integrase strand transfer inhibitor drug resistance test for resource-limited settings [version 1; peer review: not peer reviewed] F1000Research 2021, 10:306 https://doi.org/10.12688/f1000research.52954.1

First published: 20 Apr 2021, 10:306 https://doi.org/10.12688/f1000research.52954.1 